\title{
HUMANISTIC IDEAS OF A.D. SAKHAROV IN THE PHILOSOPHY COURSE FOR BACHELORS
}

\author{
Maria S.Romanova ${ }^{1 *}$, Svetlana A. Romanova ${ }^{2}$ \\ ${ }^{1}$ Assoc. Prof., PhD, Mari State University, Russia, maria.romanova@list.ru \\ ${ }^{2}$ Assoc. Prof., PhD, Mari State University, Russia, rosswet@mail.ru \\ ${ }^{*}$ Corresponding Author
}

\begin{abstract}
One of the central themes of the philosophy course at the university is the theme "Philosophy of Values". Its importance is due to the need for students (future specialists) to form a knowledge system about the universal human values. Their foundation is the humanism, which assumes to put a person, her or his dignity, rights and freedoms in the first place. The ideas of humanism have a long history. They were reflected in ancient philosophy, in the philosophy of the Renaissance, and, of course, in the philosophy of the existentialists. But they acquired particular importance in the second half of the 20th century, after two World Wars, the creation and testing of nuclear weapons. Introducing students the modern humanistic philosophy, we cannot ignore the humanistic ideas of academician Andrei Sakharov. That is why the article discusses the basic humanistic ideas of A.D. Sakharov, which have not lost their relevance in the twenty-first century.

The article presents an analysis of the model for building a democratic state in Russia, which is able to ensure the rights and freedoms of citizens, a decent standard of living and social protection. Based on the study of the articles and speeches of the scientists, modern literature on the topic, the author of the article showed the significance of the ideas of A.D. Sakharov, concerning globalization and global problems of humanity, argued the importance and humanistic orientation of the draft of the Constitution of the Union of Soviet Republics of Europe and Asia, based on the fundamental principles of the constitutional state and civil society.
\end{abstract}

Keywords: humanism, convergence, freedom, progress, globalization, global problems, humanity.

\section{INTRODUCTION}

May 21, 2021 marks the 100th anniversary from the birth of the Soviet-Russian academician, Nobel Prize laureate Andrei D. Sakharov. Many years have passed since his death in 1989, but scientific discoveries and humanistic ideas of this thinker concerning the better arrangement of society still sound modern today. It is no coincidence that 2019, in the list of the most influential Russians of the century published by Forbes magazine, Andrei Sakharov entered the top ten most famous Russians of the 20th century, along with V. Lenin, Y. Gagarin, S. Korolev, V. Putin and others (Forbes named the most influential Russians of the Century, 2017). This well-rounded educated and extremely talented person was not only a successful physicist, but also a courageous humanist of important stages in Russian history of the twentieth century the period of the so-called "stagnation" and perestroika. His ideas are relevant in the 21st century, and what is especially significant, many of them were realized, although when the scientist formulated them and bravely fought for them, they were considered sedition, and he himself was persecuted.

\section{PHILOSOPHY OF HUMANISM A.D. SAKHAROV}

Today we can state with the confidence that Sakharov's ideas on the future of mankind, on the importance of 
realizing broad human rights and freedoms have become the part of the common European humanistic philosophical thought. And here we must agree with the opinion of V. Lukin, Deputy Chairman of the International Affairs Committee of the Federation Council of the Russian Federation, that A. D. Sakharov "was and remains one of the brightest personified incarnations of the era of the second half of the 20th century - the era of the" bipolar world" (Lukin, 2020).

One of the thinker's humanistic ideas was the possibility of creating a state that would combine the principles of socialism and capitalism, since, in his opinion, both systems have disadvantages and advantages. Here he relied on the principle of dialectical development of society and, of course, rejected the Bolshevik thesis "we will destroy the whole world of violence to the ground, and then ...", and proposed a soft borrowing of the merits of two opposite socio-political systems while simultaneously rejecting their shortcomings. Academician Sakharov shared the ideas of the well-known theory of convergence, the authors of which were J. Galbraith and W. Rostow. However, we find its origins in the work of the Russian-American sociologist P. A. Sorokin "Russia and the United States" (Sakharov, 1989, p.26).

In 1968 the academician suggested that socialism is quite viable if we rid it of totalitarian and authoritarian layers. And although our country, unfortunately, followed the path of brutal capitalism during the period of initial accumulation (in our case, the theft) of capital, today we see that the ideas of socialism have been successfully implemented in their own way in many European countries, where a broad middle class, a decent level life and a high degree of social protection of the population have formed.

Russia has also moved from a market economy in the 90s of the twentieth century to a mixed economy, which presupposes, although not so high, social protection of citizens from the state.

Of course, humanity in the XXI century will have to solve a lot of difficult problems, but the main vector of its development was set precisely by such romantics as A.D. Sakharov. Progress, world peace and personal freedom, he believed, are inseparable from each other, interrelated and interdependent.

Throughout his social, political and scientific activities, the scientist acted as a humanist, defending human rights and freedoms as an integral basis for the realization of his creative potential and a decent life. In his speech "Peace, progress and human rights", written for the Nobel Peace Prize on December 1, 1975, A.D. Sakharov clearly outlined the importance of the realization of civil and political rights for social, economic, scientific and technological progress in general. And, of course, he turned out to be right, since only a free person is able to take a responsible attitude to the results of his activities, to understand its impact (positive or negative) on nature and society: humanity " (Sakharov, 1990a, p. 17).

It should be noted that already at the turn of the 60 s - 70s of the XX century, academician foresaw the danger of global problems that had just begun to appear. It seems to us that it was his experience as a scientist that made it possible to see their significance for humanity and to lay the foundation for the formation of modern social movements, which today have acquired a worldwide character and have begun to exert a significant influence on world politics. In the article " Reflections on progress, peaceful coexistence and intellectual freedom" he discusses the inevitability of globalization, its consequences, and is sure that "the disunity of mankind threatens him with death" (Sakharov, 1990b, p. 97). Only by joint efforts the peoples and states will be able to prevent thermonuclear war, poverty and hunger, ecological catastrophe and a number of other acute problems.

As a member of a group of the hydrogen bomb developers, A.D. Sakharov was well aware of the scientist's growing social responsibility to society, due to the scale of the discoveries. His main dream was that thermonuclear weapons would only deter the war, but never be used. It may seem paradoxical to many that A.D. Sakharov was both a developer of a terrible lethal weapon and a Nobel Peace Prize laureate. But this became possible and logical only because he was a true humanist and possessed not only extensive knowledge, but also important personal qualities, first of all, courage and responsibility. This combination allowed him, in our opinion, to become one of the first human rights defenders in the USSR.

It seems to us that it was precisely his deep understanding of the possible consequences of new weapons' use that led him to comprehend the need to form a new society and a new person on the principles of freedom and humanism. The fact is that only such a person is able to dispose of the achievements of scientific and technological progress correctly, direct them towards creation, and not towards destruction. This is the main attitude of the thinker, which formed the basis of his entire humanistic philosophical system, the relevance of which in the 21 st century is beyond doubt.

In addition, A.D. Sakharov understood that humanity can survive only by abandoning narrow nationalegoistic attitudes, through the active exchange of not only information, but also technologies, labor force, 
economic benefits, cultural achievements, etc. Even then, he felt the spirit of globalization, as we have already noted, which is formulated in his works as the idea of convergence. And this really happened at the turn of the XX and XXI centuries. The world, despite all the contradictions of globalization (Romanova, 2017, p. 140), is "forced" to become one, especially when people from different countries are faced with global problems.

\section{APPLICABILITY OF SAKHAROV'S IDEAS NOWADAYS}

The ideas expressed by Sakharov will help modern students to better understand the contradictions of the modern world. Today this is more relevant than ever, because mankind is increasingly threatened by manmade disasters. So, in 2020 , the world is faced with a completely new global problem - SARS-Cov-2, a virus that has infected tens of millions of people on the planet and killed more than a million people. It is clear that not a single state can solve this problem; joint and well-coordinated work of scientists, doctors and politicians from all over the world is important here.

Dreaming of a harmonious structure of society, A.D. Sakharov is an idealist at the same time. He perfectly understood that the creation of a single world state is impossible, and he envisioned the future of mankind as a confederation of independent states. Probably, he borrowed this idea from I. Kant's treatise "Perpetual Peace" (Kant, 1994, p. 43). There are no direct references to the philosopher in the works of A.D. Sakharov, but the entries in his diaries indicate that he was well acquainted with the work of I. Kant. He was always possessed by the idea of the unity of mankind as the basis for the peaceful coexistence of peoples and states with different socio-political systems, different cultures and mentality. Therefore, we cannot agree with some scientists, for example Karu-Murza, who call this idea utopian.

Perhaps there are elements of utopia and romanticism in the thinker's thoughts about the future of mankind. And this is understandable, since the life of society never proceeds according to predetermined patterns, but makes its own adjustments, because people are acting in it pursuing different goals, sometimes directly opposite. But the main basis of A.D. Sakharov's understanding of the unity of mankind is the principle of humanism. And the reality confirms this. Today we see quite successful associations of states that solve important socio-economic and political issues through supranational institutions. An example is the European Union, founded in 1992, and on the whole successfully realizing the long-standing dream of mankind about a civil society and the rule of law.

At the same time, academician already then saw the contradictions of globalization and warned, in particular, about the danger of the spread of the "intoxication of mass culture", realizing that it leads to the "stupidity" of people, reduces the level of their critical and analytical attitude to social problems, thus contributing to the very preservation and even growth of authoritarianism in politics.

Humanist thinker A.D. Sakharov most fully outlined in his draft "The Constitution of the Union of Soviet Republics of Europe and Asia", which he wrote in 1989, being a member of the Constitutional Commission created by the first Congress of People's Deputies of the USSR. It is noteworthy that the goal of the new federal state, in his opinion, should be "a happy, meaningful life, material and spiritual freedom, well-being, peace and security for the citizens of the country, for all people on Earth, regardless of their race, nationality, gender, age and social status " (Sorokin, 2020, p. 124). This humanistic idea has a long history. Even Aristotle in his treatise "Politics" argued that the main goal of the state is to make as many citizens as possible happy. It is clear that it was concretized by A.D. Sakharov in accordance with the state of society at the end of the twentieth century. He pays special attention to the need to ensure peace and equality of all peoples and states, noting that "the global goals of human survival have priority over any regional, state, national, class, party, group and personal goals.

In his project, A.D Sakharov consistently outlined the important principles of the formation of post-perestroika Russia, which became basic in the Constitution of the Russian Federation in 1993, adopted by a general referendum, when the academician was no longer alive. These are ideas about the separation of powers, about the diversity of ownership forms, about the priority of the rights of citizens' freedoms, etc. All of them were basically humanistic, although, unfortunately, they have not yet been fully realized. As human rights defenders, academician paid great attention in his draft Constitution to human and civil rights and freedoms. Thus, in his opinion, no one can be subjected to torture and ill-treatment; in peacetime, execution should be prohibited, medical and psychological experiments on people without the consent of the subjects should be inadmissible.

\section{CONCLUSION}

Thus, freedom and human rights, his dignified existence, good attitude to the surrounding nature, humanity, 
to each individual person - this is the quintessence of the humanistic philosophy of A.D. Sakharov. His ideas are important for a more complete understanding of the main principles of humanism by modern students and their practical implementation in everyday life and in future professional activities. The fact that intolerance towards "strangers", and often towards "friends", disregard for the rights of other people, nations and states, unfortunately have not yet outlived their usefulness. Therefore, the humanistic ideas of A.D. Sakharov are still relevant and modern.

\section{REFERENCE LIST}

Forbes named the most influential Russians of the century (2017). Vedomosti. 31.08.2017. https://www.vedomosti.ru/politics/news/2017/08/31/731794-forbes-nazval

Kant, I. Perpetual peace .Works in 8 volumes. Vol. 7. M.: CHORO, 1994, 495 p.

Lukin V. Titan. No corrosion. Rossiyskaya Gazeta. 18.07.2020. URL: https://rg.ru/2020/07/18/pochemunelzia-zabyvat-andreia-saharova-kak-velikogo-fizika-i-grazhdanina.html

Sakharov, A.D. Constitution of the Union of Soviet Republics of Europe and Asia. New time. 1989. No. 52 (special issue), pp. 26-27.

Sakharov, A.D. Nobel lecture Peace, progress, human rights. Peace, progress, human rights: Articles and speeches. Leningrad, 1990. 128 p.

Sakharov, A.D. Reflections on progress, peaceful coexistence and intellectual freedom. Peace, progress, human rights: Articles and speeches. Leningrad, 1990. 128 p.

Sorokin, P. Russia and the United States. Sankt-Petersburg, 2020. 330 p.

Romanova, M.S., Romanova, S.A., Ivanova, I.G., Kozlov, P.S. Transformation of Russian and European Mentality in the Context of Globalization. Abstracts \& Proceedings of SOCIOINT 2017- 4th International Conference on Education, Social Sciences and Humanities, 10-12 July 2017. Dubai, UAE. pp.140-143. ISBN: 978-605-82433-1-6. http://www.ocerint.org/socioint17\%20epublication/abstracts/a240.html 